\title{
On Scalar Predicative PPs in Spanish ${ }^{1}$
}

\author{
Isabel Oltra-Massuet and Isabel Pérez-Jiménez \\ Universitat Rovira i Virgili, CCHS-Consejo Superior de Investigaciones Científicas \\ isabel.oltra@urv.cat, isabel.perez@cchs.csic.es
}

\section{Abstract}

We assert the cross-categorial significance of the notion of scalarity, focusing on bare PPs headed by sin/con 'without/with'. Con-PPs are always non-gradable. With sin-PPs, the mereological properties of the $\mathrm{N}$-complement of $\mathrm{P}$ determine the gradability of the PP: mass Ns yield gradable PPs; count Ns generate nongradable PPs. We investigate the locus of scalar meaning in PPs and how this is compositionally determined. We conclude that the quantificational properties of $\mathrm{P}$, together with the algebraic part structure and the type of scale of the $\mathrm{N}$-complement of $\mathrm{P}$ are involved in determining the scalar semantics of bare PPs.

\section{Introduction}

The goal of this paper is to analyze the scalar properties of so-called bare PPs headed by $\sin /$ con 'without/with', illustrated in the shaded cells in Table 1, in their function as postnominal modifiers within a DP. Bare PPs are PPs that have a bare (singular or plural) noun in complement position (Grønn et al. 2010, Le Bruyn et al. 2011).

Con-headed PPs in (1b) always express non-gradable properties and cannot combine with degree modifiers. In the case of sin, we argue that the mereological properties of the noun selected by the preposition mold the scalarity of the property expressed by the entire PP. Degree quantification is possible when the noun complement of sin is a mass noun, as in una habitación muy sin luz in (1a) which roughly means 'a very lightless room'. However, when sin selects a count noun such as corbata 'tie', the PP is non-gradable and combination with a degree quantifier becomes ungrammatical.

1 The investigation underlying this work has been partially funded by MICINN projects FFI2009-071114/FILO and FFI2010-22181-C03-01. We thank K. Arregi, I. Bosque, O. Fernández Soriano, C. Kennedy, L. McNally, H. de Swart, and the members of the LyCC group, especially E. Castroviejo and V. Demonte, for comments and discussion of (not always shared) ideas presented in this paper.

\section{(cc) BY-NC-ND}


Table 1.

Bare PPs headed by sin/con 'without/with'

\begin{tabular}{|l|l|l|l|l|l|}
\hline & & \multicolumn{2}{|c|}{ N-Complement: mass noun } & \multicolumn{2}{c|}{ N-Complement: count noun } \\
\hline (1a) & $\begin{array}{l}\text { sin } \\
\text { without }\end{array}$ & $\begin{array}{l}\text { una habitación } \\
\text { sin luz } \\
\text { a room w/o light }\end{array}$ & $\begin{array}{l}\text { una habitación } \\
\text { muy sin luz } \\
\text { a room very w/o } \\
\text { light }\end{array}$ & $\begin{array}{l}\text { un hombre } \\
\text { sin corbata } \\
\text { a man w/o tie }\end{array}$ & $\begin{array}{l}\text { *un hombre } \\
\text { muy sin corbata } \\
\text { a man very w/o } \\
\text { tie }\end{array}$ \\
\hline (1b) & $\begin{array}{l}\text { con } \\
\text { with }\end{array}$ & $\begin{array}{l}\text { una habitación } \\
\text { con luz } \\
\text { a room w/ } \\
\text { light }\end{array}$ & $\begin{array}{l}\text { *una habitación } \\
\text { muy con luz } \\
\text { a room very w/ } \\
\text { light }\end{array}$ & $\begin{array}{l}\text { un hombre } \\
\text { con corbata } \\
\text { a man w/ tie }\end{array}$ & $\begin{array}{l}\text { *un hombre } \\
\text { muy con } \\
\text { corbata } \\
\text { a man very } \\
\text { w/ tie }\end{array}$ \\
\hline
\end{tabular}

w/o: without; w/: with

This initial paradigm poses the questions in (2).

(2a) What are the factors that determine the gradability of sin-/con-headed PPs?

(2b) What is the locus of scalar semantics in the structure of bare PPs, specifically of those headed by sin? What is the contribution of the preposition and of the noun it selects to the scalar properties of the whole?

(2c) How is the notion of scalarity expressed in the syntax and semantics of bare PPs? More specifically, how is scalar meaning compositionally determined in these PPs?

Although the cross-categorial nature of scalarity has been acknowledged in the literature (Sapir 1944, Bolinger 1972), there is no systematic study on the scalar structure of PPs - with the exception of directional PPs (see e.g. Grolla 2004, Den Dikken 2010, Svenonius 2010, among others) -, and, to the best of our knowledge, the type of PP that is the topic of this paper has not been investigated with respect to scalarity. We believe that the study of bare PPs that express properties can help answer questions with far-reaching consequences (that will not be tackled here) such as whether we can establish cross-categorial generalizations about the interaction among different types of syntacticosemantic properties: countability-gradability/scalarity, scalarity-telicity, countability-telicity, or whether there is a cross-categorial universal typology of scale structures.

\section{Theoretical Background}

In this section, we outline the main theoretical assumptions that will be relevant for our proposal. 


\subsection{Scalarity and Gradation}

We take a scalar predicate to be a predicate that expresses a scale, where a scale is defined as in (3).

(3) A scale is "a dense linearly ordered set of points, or 'degrees', where the ordering is relativized to a dimension." (Kennedy 1999:43)

Thus, a scale must include three elements: a set of degrees [D], with a linear ordering $[R]$, in a specific dimension $[\Delta]$. Scales associated with scalar predicates (e.g. adjectives) vary in structure. An adjective like alto 'tall' denotes a set of degrees of height which are linearly ordered as represented in (4). This scale has neither a minimal nor a maximal value and is therefore an open scale. On the other hand, an adjective like despierto 'awake' also denotes a set of linearly ordered degrees of awakeness, but in this case, the scale has a minimal value, as in (5), i.e. there is a minimal positive point of awakeness below which one can no longer predicate the awakeness of something. It is therefore a lower-closed scale.

(4)

(5)

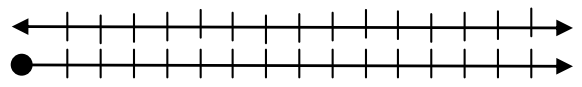

Scalar predicates can combine with degree modifiers, (6a), can appear in comparative structures, (6b), and some of them accept measure phases (Kennedy \& McNally 2005 [KEM henceforth]), (6c).

(6a) muy alto 'very tall', poco despierto 'little awake'

(6b) más alto que Pedro 'taller than Pedro', más despierto que Juan 'more awake than Juan'

(6c) 3 metros de alto ' 3 meters of tall'

We assume that these modifiers are generated in a degree phrase (DegP) that merges over the projection occupied by the scalar predicate, e.g. the adjective in (7) (cf. Kennedy 1999, Corver 1997).

(7)<smiles>[Mg][Ba][Ba]</smiles>

For languages like English, K\&M (2005) have shown that different degree modifiers are sensitive to the scale structure of the predicate they combine with. Spanish lacks such a systematic analysis, but as we will show, the scale structure 
of the complement of $\sin$ is crucial for the interpretation of the entire PP. In order to determine the scale structure of the PPs, we use the correlation established in K\&M (2005) for adjectives, according to which, relative adjectives are linked to open scales while closed scales are associated with absolute adjectives. For instance, an adjective like tall is relative, because its meaning is contextually determined in relation to some standard degree of tallness for a comparison class, so that a sentence like (8a) can be true or false depending on the context provided by the comparison class; therefore, it can give rise to implications like (8b). However, a sentence like (9), with an absolute adjective, expresses that Juan has some degree of the property 'being awake' that is different from zero, independently of the context.

(8a) Juan es alto. 'Juan is tall'

Situation: Juan is $1.50 \mathrm{~m}$ tall.

i. Comparison class: 10 year old children.

Standard degree for 10 year old children: $1.33 \mathrm{~m}$.

$\rightarrow$ The sentence is true.

ii. Comparison class: 40 year old men.

Standard degree for 40 year old men: $1.65 \mathrm{~m}$.

$\rightarrow$ The sentence is false.

(8b) Juan es más alto que Pedro, aunque los dos son bajos (para ser jugadores de baloncesto).

'Juan is taller than Pedro, although both are short (as basketball players)'

(9) Juan está despierto. 'Juan is awake'

For example, we can determine that the PP sin luz 'without light' in, for instance, una habitación sin luz 'a room without light' expresses a gradable contextually-dependent property, i.e. a relative property. We know that the property is relative because we can establish comparisons of the type tenemos una habitación más sin luz que otra, pero ambas tienen luz 'we have a room more without light than another, but both have light'. Consequently, the predicate $\sin$ luz 'without light' will be associated with an open scale.

\subsection{The Mereological Structure of Nouns}

We claim that the mereological structure of the noun complement of sin specifically, the count/mass distinction - is crucial to determine the scale structure of the PP it heads.

Count nouns, like tie, denote entities that cannot be further subdivided while keeping their nature and name; so, a part of a tie is not a tie. Conversely, mass nouns have cumulative reference; they denote substances that "can be 
divided ad infinitum while keeping their nature and name, such as water" (Bello 1847:\$123, from Bosque 1999:8, our translation), so that a part of water is also water. They differ in the type of quantifiers they take. For instance, only count nouns accept numeral quantifiers, as in Table 2 (1); or, only mass nouns allow indefinite quantifiers like singular mucho in (2). Nouns like color, which accept both types of quantifiers, illustrate the fact that certain nouns are ambiguous, so we can have much color and also three colors.

Table 2.

Mass vs. Count nouns. Distinguishing criteria (not exhaustive).

\begin{tabular}{|c|c|}
\hline Mass Noun & Count Noun \\
\hline \multicolumn{2}{|l|}{ 1. With numeral quantifiers and multipliers } \\
\hline $\begin{array}{l}\text { "tres }\{\text { importancias, humos\} } \\
\text { three importances, smokes }\end{array}$ & $\begin{array}{l}\text { tres }\{\text { corbatas, colores\} } \\
\text { three }\{\text { ties, colors }\}\end{array}$ \\
\hline $\begin{array}{l}\text { "muchas importancias }{ }^{2} \\
\text { many importances }\end{array}$ & $\begin{array}{l}\text { muchas \{corbatas, colores\} } \\
\text { many \{ties, colors }\}\end{array}$ \\
\hline \multicolumn{2}{|c|}{ 2. With indefinite quantifiers (non-cardinals) } \\
\hline $\begin{array}{l}\text { poca/mucha \{energia, importancia, luz\} } \\
\text { little/much }\{\text { energy, importance, light }\}\end{array}$ & $\begin{array}{l}\text { "poca corbata } \\
\text { little tie }\end{array}$ \\
\hline \multicolumn{2}{|l|}{$\begin{array}{l}\text { poco/mucho }\{\text { humo, color }\} \\
\text { little/much }\{\text { smoke, color }\}\end{array}$} \\
\hline \multicolumn{2}{|l|}{ 3. With the adjectival quantifier medio } \\
\hline $\begin{array}{l}\text { "media }\{\text { energía, importancia\} } \\
\text { half energy, importance }\end{array}$ & $\begin{array}{l}\text { media corbata } \\
\text { half tie }\end{array}$ \\
\hline \multicolumn{2}{|l|}{ 4. In the construction una cantidad de N } \\
\hline $\begin{array}{l}\text { una cantidad de \{energía, humo\} } \\
\text { a quantity of energy, smoke }\end{array}$ & $\begin{array}{l}\text { "una cantidad de corbata } \\
\text { a quantity of tie }\end{array}$ \\
\hline
\end{tabular}

\subsection{The Structure of Postnominal Modifiers}

With respect to postnominal modifiers, we assume that they are generated in Romance as predicates in clause structure. Specifically, as complements inside a predicate phrase (PredP), (Campos \& Stavrou 2004, see also Bowers 2001). ${ }^{3}$ Hence, the structure for una habitación sin luz 'a room without light' is the one in (10). The PP expresses a property that is predicated of a subject.

$\mathbf{2}$ This type of quantification is possible with mass nouns, but only with a concomitant recategorization process, as in muchas energías 'many energies' or muchas luces 'many lights' (see Bosque 1999).

3 See Alexiadou et al. (2007) for a discussion of alternative proposals. 
(10)

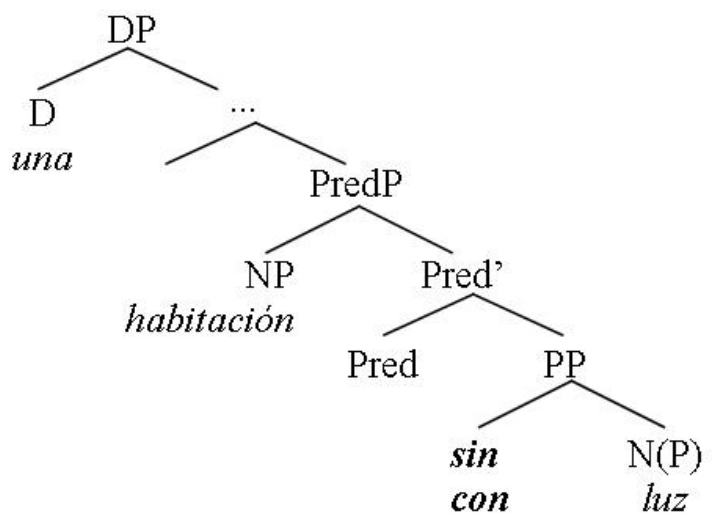

The syntactic structure for una habitación muy sin luz 'a room very without light' is represented in (11). The degree modifier is generated in a degree phrase that merges above the complement of Pred ${ }^{\circ}$ (Bowers 2001), i.e. above the bare PP in the case at hand. ${ }^{4}$

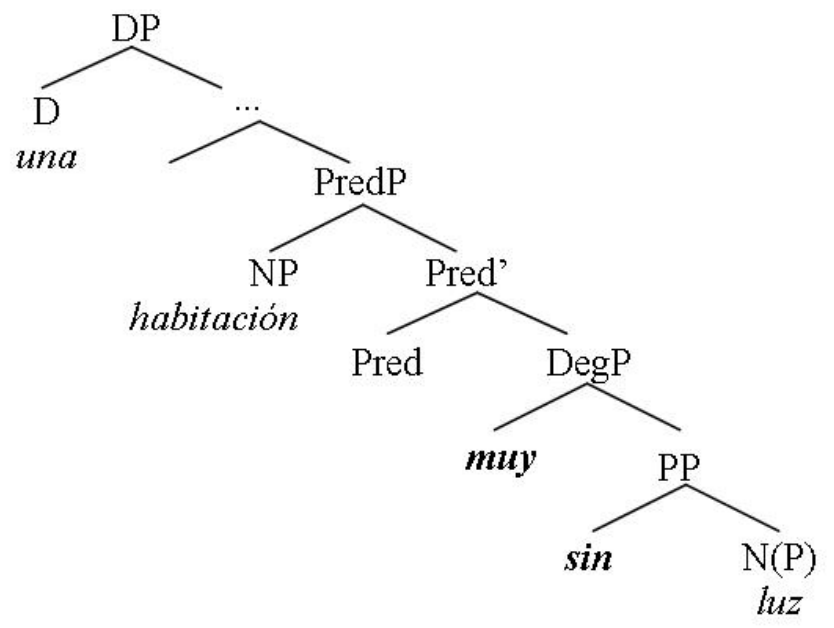

$4 \mathrm{~A}$ Degree projection is also postulated within the structure of locative and directional PPs in Den Dikken (2010) and Svenonius (2010). 


\section{Scalarity in Sin-Headed Bare PPs}

In this section, we explore the scalar properties of sin-headed bare PPs. As we have already mentioned, the mereological structure of the noun complement of sin (whether count or mass) determines the gradability properties of the entire PP.

When sin selects a bounded or count noun like corbata 'tie', (12) - remember that these nouns are incompatible with the singular quantifier mucho/mucha 'much-masc/fem', (13) - the PP conveys a non-gradable negative property (that can be paraphrased as 'absence of'), and combination with a degree quantifier is not possible, (14).

(12) un hombre sin corbata, un vestido sin cinturón

a man w/o tie a dress w/o belt

(13) *sin mucha corbata, "sin mucho cinturón w/o much tie w/o much belt

(14) *un hombre muy sin corbata, "un vestido más sin cinturón que otro a man veryw/otie a dress more w/o belt than other

On the contrary, when sin selects an unbounded or mass noun as complement, (15a), the PP expresses a gradable property, (15b).

(15a) un ambiente sin humo, una habitación sin luz a environment w/o smoke a room w/o light (15b) un ambiente muy sin humo, una habitación muy sin luz a environment very w/o smoke a room very w/o light

Within the class of mass nouns, we show in the next subsections that the subclassification in (16) is crucial to explain the scalar properties of sin-headed bare PPs. Recall that all these nouns are compatible with the singular quantifier mucho/mucha 'much-masc/fem', or some other construction from the set of diagnoses in Table 2 for plurals, such as una cantidad de 'a quantity of'.

(16) Mass nouns

(16a) Scalar nouns (nouns expressing a scale)

Nouns expressing a linear scale

Dimension nouns: volumen 'volume' (mucho volumen 'much volume')

Quality nouns: importancia 'importance' (mucha importancia 'much importance')

Nouns expressing a non-linear scale: color 'color' (mucho color 'much color')

(16b) Stuff-denoting nouns: luz 'light' (mucha luz 'much light')

(16c) Plural nouns: piedras 'stones' (una cantidad de piedras 'a quantity of stones') 


\subsection{Scalar Nouns}

Within the class of scalar nouns, we establish a difference between nouns denoting non-linear scales like color, and nouns denoting a linear scale, which can be further subdivided into dimension nouns like volume and quality nouns like interest, as in (16) above.

Nouns like volumen 'volume' (or energía 'energy') can express a physical dimension, a magnitude that can be measured on a numerical scale. Under this interpretation, they are scalar nouns that express a set of linearly ordered values, with a minimal point and without a maximal value, (17)-(18). These nouns admit measure phrases that select a specific value on the scale, (19).

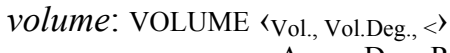

$$
\Delta \quad \mathrm{D} \quad \mathrm{R}
$$

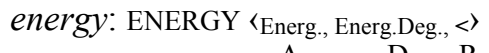

Minimal point: $0 \mathrm{~m}^{3} / 0$ joules

(19) $5 \mathrm{~m}^{3}$ de volumen, 200 gigajulios de energía

$5 \mathrm{~m}^{3}$ of volume, 200 gigajoules of energy

However, when these (mass and scalar) nouns are selected by sin, the property expressed by the PP is non-gradable, (20), which seems to go against our initial generalization that a bare PP is gradable whenever the noun complement of $\sin$ is a mass noun. To account for these cases, we must explore the interaction between the specific scalar properties of dimension nouns and the scalar properties of sin.

(20a) *una esfera muy sin volumen (= casi un círculo)

a sphere very w/o volume almost a circle

(20b) *un rayo muy sin energía (= un rayo de pocos julios)

a ray very w/o energy a ray of few joules

Sin has been analyzed as a (negative) quantifier, since it licenses negative polarity items in many languages (also in Spanish, (21)).

(21) *Vino con nadie - Vino sin nadie ${ }_{\mathrm{NPI}}$ 'He came *with/without anybody' (See Bosque 1980 for Spanish; Espinal 2002 for sense in Catalan; de Swart \& Sag 2002, Corblin et al. 2004 for sans in French) 
Our claim is that when sin heads a PP with a scalar noun, it projects the external argument onto the minimal value on the scale associated with the noun. In the case of esfera sin volumen 'sphere without volume', (22), this minimal value corresponds to degree zero, because volumen denotes a lower-closed scale, (23). A sphere without volume is, therefore, a sphere with a volume of $\mathrm{Om}^{3}$, i.e. a circle.

(22)

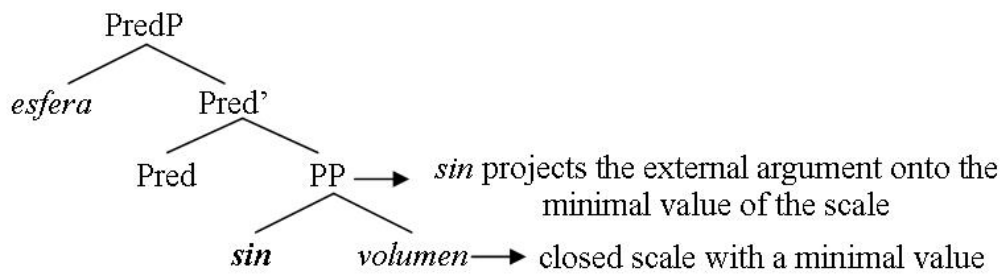

(23)

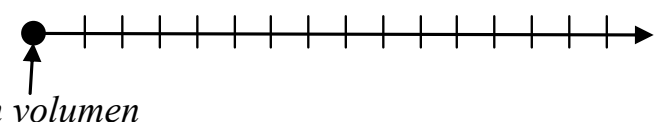

sin volumen

Sin, (24), behaves as a measure phrase, (25), or degree quantifier, (26): it combines with predicates expressing a scale and sets a specific value on that scale: the minimal value. ${ }^{5}$ (See K\&M 2005 on measure phrases).

(24) $[[\sin ]]=\lambda G \lambda x \cdot \exists d\left[d=\operatorname{Min}\left(S_{G}\right)(C) \Lambda G(d)(x)\right]$

(25) $\left[\left[5 \mathrm{~m}^{3}\right]\right]=\lambda \mathrm{G} \lambda x \cdot \exists d\left[\mathrm{~d}>5 \mathrm{~m}^{3} \Lambda \mathrm{G}(\mathrm{d})(\mathrm{x})\right]$

(26) Common denotation for degree quantifiers/measure phrases

$[[\operatorname{Deg}(P)]]=\lambda G \lambda x . \exists d[R(d) \Lambda G(d)(x)](K \& M$ 2005:367)

( $R$ corresponds to the restriction over degrees that distinguishes the semantics of degree morphemes among themselves)

Once sin sets a value on the degree scale, combination with a degree quantifier as in 'una esfera muy sin volumen 'a sphere very without volume' becomes impossible. As with adjectives, (27), once some scalar property has been assigned some specific value by means of a measure phrase, modification by a degree quantifier is not possible.

(27a) very old - degree quantifier

(27b) two years old - measure phrase

(27c) *very two years old

5 Note that we assert that sin combines with scalar predicates. The impossibility that $\sin$ combines with adjectives must be analyzed as a strictly syntactic restriction. 
Consider now the grammatical example in (28a). In this case, the noun volumen does not denote a dimension of the object, a magnitude, but a quality or property of the haircut. ${ }^{6}$ These cases should be treated on a par with (29), where we have abstract nouns like importancia 'importance' or interés 'interest' that appear in gradable bare PPs.

(28a) una melena muy sin volumen ( $\approx$ una melena con poco volumen) a haircut very w/o volume $(\approx a$ haircut $w /$ little volume) (28b) una persona muy sin energía ( $\approx$ una persona con poca energía) a person very w/o energy $(\approx a$ person $w /$ little energy) (29) un asunto muy sin importancia; una noticia muy sin interés a issue very w/o importance; a news very w/o interest

As claimed in the literature, these quality nouns have a reading in which they measure the degree to which some quality is applied to a certain entity (NGRALE: § 12.1i, § 22.13m; Zwarts 1992: 154). ${ }^{7}$ In this interpretation, these nouns are scalar. The scale they denote is open, (30)-(31). The preposition sin, by virtue of its semantics, forces a process of scalar coercion on that scale. When sin combines with a noun that denotes an open scale, the property expressed at the PP level denotes a bounded open scale (Kennedy 2007, n. 28), i.e. a scale that approaches a zero value without including it.
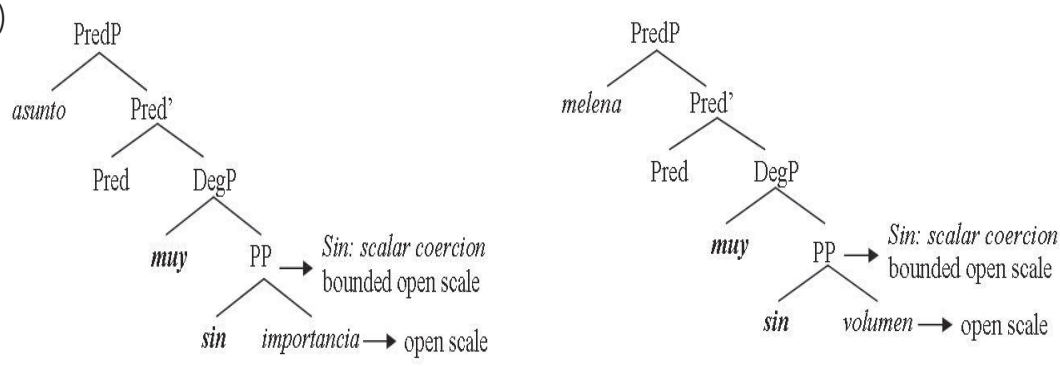

6 In these cases, the external argument of PredP co-determines the dimension expressed by the noun complement of $P$, and hence, the scalar structure of the property expressed by the PP. Note that the interpretation of multidimensional gradable adjectives like seco 'dry' as relative or absolute adjectives also varies depending on the entity they are predicated of (camisa seca 'dry shirt' vs. clima seco 'dry weather', K\&M 2005:49).

7 They can also express the name of a property, (i). Compare this meaning with the degree meaning, (ii): "Ana possesses certain degree of intelligence that is higher than the degree of intelligence of Pedro".

(i) La inteligencia de Ana la hizo famosa. 'Ana's intelligence made her famous'

(ii) La inteligencia de Ana es mayor que la de Pedro. 'Ana's intelligence is greater tan Pedro's' 
Consequently the scale of the property formed at the PP level is also open; note the implication patterns in (32).

(32a) Este asunto parece más sin importancia que ese para el público general, this issue seems more w/o importance than that for the general public general, aunque ambos pueden ser importantes. general although both can be important

(32b) una melena más sin volumen que otra, aunque ambas tienen a haircut more w/o volume than another,though both have bastante volumen plenty.of volume

As an open scale where no value has been set, it is possible to add a degree modifier. In muy sin importancia, or muy sin volumen in (33), muy 'very' indicates that the subject possesses the property in a degree that is close to the minimal value.

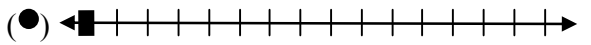
muy sin \{importancia/volumen\} 'very without \{importance/volume\}'

Now consider nouns like color 'color', sabor 'taste', olor 'smell', which have a mass interpretation, (34a), and a count interpretation, (34b). As expected, when color is a count noun, it gives rise to non-gradable PPs, as in (35b). When it is a mass noun, it gives rise to a gradable PP, as in (35a).

(34a) mucho color

much color

(34b) dos, tres, muchos ... colores

two three many colors

(35a) una foto muy sin color (= descolorida) a photo very w/o color (= faded)

(35b) líquido para obtener [fotos sin color] (= en blanco y negro) $\rightarrow$ *muy sin color liquid to obtain photos w/o color ( $=$ in black and white) $\rightarrow$ *very w/o color

It has been claimed in the literature (Fleischhauer \& Gamerschlag 2010) that nouns like color denote non-linear scales, i.e. scales with a dimension and a set of values, whose parameter of 'ordering relation' is not specified, (36).

(36a) color: COLOR 〈Color., Color. Val., Rc〉

$[R c=$ ordering determined by context $]$

$\Delta \quad \mathrm{D} \quad \mathrm{R}$ 
(36b)

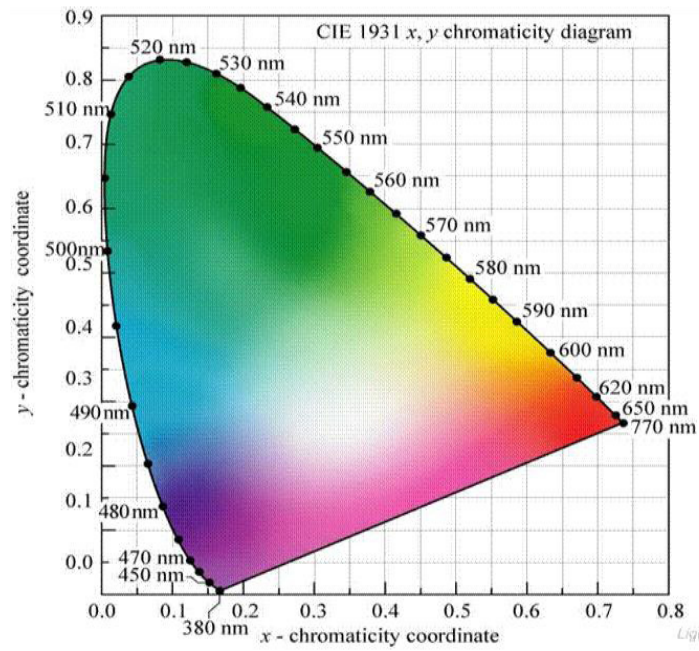

[From: E. F. Schubert, 2006, Light-Emitting Diods, CUP]

Given that the scale structure of the noun is inherited at the PP level and nonlinear scales cannot be graded, because gradability requires an ordering relation between the values, what is the source of gradability in (35a)? We claim that sin selects a linear scalar dimension associated with one of the properties expressed in the meaning of the noun, e.g. 'intensity' or 'brightness'. The intensity scale or the brightness scale are linear and open, so that sin coerces them into bounded open scales. Consequently, the PP can be graded.

\subsection{Stuff-denoting Nouns}

When the complement of $\sin$ is a stuff-denoting noun, the bare PP is gradable, (37).

(37a) un ambiente muy sin humo

a environment very w/o smoke

(37b) una habitación muy sin luz

a room very w/o light

(37c) un rostro muy sin maquillaje

a face very w/o make-up

(37d) un café muy sin azúcar

a coffee very w/o sugar

Again, the mereological (cumulative) structure of the $\mathrm{N}$ complement of sin gives rise to the expression of a gradable property at the level of PP; roughly, the property 
of tener humo 'having smoke' or tener luz 'having light'. There is a homomorphic relation between the referential properties of the noun and the scale structure expressed by the PP. Given that these nouns are unbounded and cumulative, the scale associated with the property expressed by the PP is open. In fact, this scale is a bounded open scale, given the semantics of $\sin$, and degree modification is possible. ${ }^{8}$

\subsection{Plural Nouns}

As for plural nouns, since they also have cumulative reference (Quine 1960, Link 1983), they give rise to gradable sin-headed bare PPs, as expected, (38).9

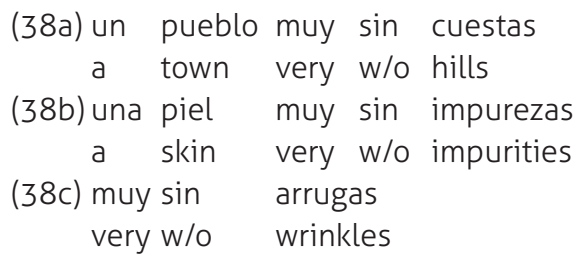

\section{Scalarity in Con-Headed Bare PPs}

PPs introduced by the preposition con are non-scalar and non-gradable, independently of the mereological and scalar properties of the noun, (39). ${ }^{10}$

8 However, cases like those in (i) are not possible. An important difference between (i) and the examples in the text, which could open a way to explain this contrast, is that in (i) there is a relation of inalienable possession between the nouns in specifier and complement of PredP respectively.

(i)

$\begin{array}{cllll}\text { a. *un } & \text { pozo } & \text { muy } & \text { sin } & \text { agua } \\ \text { a } & \text { well } & \text { very } & \text { w/o } & \text { water } \\ \text { b. *una } & \text { paella } & \text { muy } & \text { sin } & \text { arroz } \\ \text { a } & \text { paella } & \text { very } & \text { w/o } & \text { rice }\end{array}$

9 There are also examples judged as ungrammatical by the speakers consulted ("un árbol muy sin hojas 'a tree very without leaves', "una escuela muy sin estudiantes 'a school very without pupils'). There also seems to be a relation of inalienable possession in these cases.

$\mathbf{1 0}$ There are also cases like un chicle muy con sabor a frutas 'a chewing gum very with taste to fruit', muy con olor a jazmin 'very with smell of jasmine' (Google) that are judged as grammatical by the same native speakers that reject "un chicle muy con sabor 'a chewing gum very with taste', "muy con olor 'very with smell'. Although we have no account for this contrast at present, it is obvious that the presence of a complement of the noun plays a central role. 
(39a) count noun

un chico con corbata - "un chico muy con corbata

a boy w/ tie a boy very w/ tie

(39b) mass noun - stuff-denoting noun

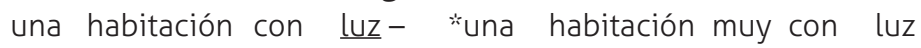

a room w/ light a room very w/ light

(39c) mass noun - scalar noun: dimension

una melena con volumen - *una melena muy con volumen

a haircut w/ volume a haircut very w/ volume

(39d) mass noun - scalar noun: quality

un asunto con importancia - *un asunto muy con importancia

a issue $w /$ importance a issue very $w /$ importance

(39e) noun denoting a non linear scale

un vino con sabor - "un vino muy con sabor

a wine $\mathrm{w} /$ taste a wine very $\mathrm{w} /$ taste

(39f) plurals

una piel con impurezas - *una piel muy con impurezas

a skin $w /$ impurities a skin very $w /$ impurities

The crucial question is where the difference between sin and con lies. In our analysis, sin as a negative operator has access to the semantic structure of its complement and can modify it. Con is not an operator. We believe that this is the research path to account for the - semantic and possibly also structural - differences between sin and con. This will be our next step in the investigation of these data.

\section{Conclusions}

In this paper we have analyzed the scalar properties of some bare predicative PPs in Spanish, and we have established that the factors involved in determining the gradability of these PPs are: a) the quantificational nature of the preposition, and $b)$ the semantic properties relative to the mereological structure and the scalarity of the noun complement of $P$, in the case of sin-headed PPs. Hence, a first conclusion that can be drawn on the cross-categorial status of the notion of scalarity is that the scalar properties of bare PPs that express properties parallel those exhibited by adjectives. There are bare PPs that express scalar properties and also bare PPs that express non-gradable properties. As with adjectives, the 
external argument that bare PPs are predicated of can determine the scalar properties of the properties expressed at the PP level (multidimensional PPs).

We have further established certain preliminary distinctions in the realm of scalar nouns that deserve a more thorough analysis. We have distinguished between scalar nouns denoting a linear scale (open or closed) and scalar nouns denoting a non-linear scale, a property that has syntactic as well as semantic consequences.

There are many open issues, and other questions remain still unexplored. Among the former, a common semantics for sin and con is still to be developed, as well as a unified semantics for sin that accounts for its combination with both count and mass nouns. Since sin can combine with any type of noun, be it a proper name as in una fiesta sin Juan 'a party without Juan', or any kind of count noun, as in una persona sin \{hogar, trabajo, enemigos\} 'a person without home, work, enemies', the proposal that the semantics of sin operates on the scale structure of its complement entails the assumption that all nouns are scalar entities. One could assume a trivial scalarity for count nouns that, for instance, could express a binary scale $[0,1]{ }^{11}$ Another possibility would be to assume GrØnn et al.'s (2010) and Le Bruyn et al.'s (2011) proposal that bare nouns appearing as complements of $\mathrm{P}$ contain an existential quantification. Whereas in the presence of a count noun we would predicate the existence of certain individual, in the case of mass nouns it would quantify over the existence of certain degree of the property expressed in the noun. The negative quantification of sin would operate on the existence of something in both cases, an individual $x$ or a certain degree $d$. Whereas in the former we would obtain $\neg \exists x$, in the latter quantification would be over the degree of a gradable property, $\neg \exists \mathrm{d}$. In this second case, the effect of negative quantification would be a scale reversal, so that we would obtain a certain minimal degree below the standard of the comparison class that would allow for further degree modification. With count nouns, we would get the absence of the individual.

Among the unexplored questions, we can find the impossibility of having double quantification in the phrases under study, (40), or a conspicuous crosslinguistic contrast. In languages like Catalan, sin-headed bare PPs can never be graded, (41).

(40) *un asunto muy sin mucha importancia
a issue very w/o much importance

11 Thanks to $\mathrm{H}$. de Swart and C. Kennedy for suggesting the lines of reasoning summarized in the text. See Kennedy (2012) for an analysis of all nouns as measure functions. 
Major Trends in Theoretical and Applied Linguistics

(41) *un assumpte molt sense importància

a issue very w/o importance

The paradigm we have described in this paper cannot be found in other Romance languages, like French or Italian, or in Germanic languages, like English or German. It is thus necessary to investigate the property - apparently unique to Spanish - that allows the existence of these cases. 


\section{References}

Alexiadou, A., L. Haegeman and M. Stavrou. 2007. Noun phrase in the generative perspective, Berlin, Mouton de Gruyter.

Bello, A. [1847] 1981. Gramática de la lengua castellana, edited by R. Trujillo, Tenerife.

Bolinger. D. 1972. Degree words, The Hague, Mouton.

Bosque, I. 1980. La preposición sin, Lingüística Hispánica, 3: 71-85.

Bosque, I. 1999. El nombre común, in I. Bosque and V. Demonte (eds.), Gramática descriptiva de la lengua española, Madrid, Espasa, 1:3-75.

Bowers, J. 2001. Predication, in M. Baltin and C. Collins (eds.), The handbook of contemporary syntactic theory, Oxford, Blackwell: 299-333.

Campos, H. and M. Stavrou. 2004. Polydefinites in Greek and Aromanian, in O. Tomic (ed.), Balkan syntax and semantics, Amsterdam, John Benjamins: 137-173.

Corblin, F., V. Déprez, H. de Swart and L. Tovena. 2004. Negative concord, in F. Corblin and H. de Swart (eds.). Handbook of French Semantics, Stanford, CSLI Publications: 427-461.

Corver, N. 1997. The internal syntax of the Dutch extended adjectival projection, Natural Language and Linguistic Theory, 15: 289-368.

Den Dikken, M. 2010. On the functional structure of locative and directional PPs, in G. Cinque and L. Rizzi (eds.), Mapping spatial PPs, Oxford, Oxford University Press: 74-126.

Espinal, M.T. 2002. La negació, in J. Solà et al. (eds.) Gramàtica del català contemporani. Barcelona: Empúries, Vol. 3:2727-2797. 
Fleischhauer, J. and T. Gamerschlag. 2010. The interaction of verbs and arguments in scalar composition, handout of the talk given at Workshop on the lexicon-syntax interface: Verb meaning, event semantics and argument structure, UAB, December 2-3 2010.

Grolla, E. 2004. Prepositions, scales and telicity: A case study, in Proceedings of the 23rd West Coast Conference on Formal Linguistics, Somerville, MA, Cascadilla Press: 293-303.

Grønn, A., B. Le Bruyn, H. de Swart and J. Zwarts. 2010. Bare PPs across languages, Ms. Utrecht University.

Kennedy, C. 1999. Projecting the adjective. The syntax and semantics of gradability and comparison, New York \& London, Garland.

Kennedy, C. 2012. The Composition of Incremental Change. In V. Demonte and L. McNally (eds), Telicity, Change, State: A Cross-categorical View of Event Structure, Oxford, Oxford University Press, 103-121.

Kennedy, C. 2007. Vagueness and grammar: The semantics of relative and absolute gradable adjectives, Linguistics and Philosophy, 30.1:1-45.

Kennedy, C. and L. McNally. 2005. Scale structure, degree modification, and the semantics of gradable predicates, Language, 81 : 345-381.

Le Bruyn, B., H. de Swart and J. Zwarts. 2011. Mass-count distinctions in bare PPs, Ms. Utrecht Institute of Linguistics OTS, Utrecht University.

Link, G. 1983. The logical analysis of plurals and mass terms: A lattice theoretical approach, in R. Bäuerle, C. Schwarze and A. von Stechow (eds.), Meaning, use, and the interpretation of language, Berlin, de Gruyter: 302-323.

RAE y Asociación de Academias de la Lengua Española. 2009. Nueva gramática de la lengua española, Madrid, Espasa. [NGRALE]

Quine, W.V.O. 1960. Word and object, Cambridge, MA, The MIT Press.

Sapir, E. 1944. Grading: A study in semantics, Philosophy of Science, 11: 93-116.

Svenonius, P. 2010. Spatial P in English, in G. Cinque and L. Rizzi (eds.), Mapping spatial PPs, Oxford, Oxford University Press: 127-160. 
De Swart, H. and I.A. Sag. 2002. Negation and Negative Concord in French. Linguistics and Philosophy 25: 373-417.

Zwarts, J. 1992. $X^{\prime}$-syntax/X'-semantics. On the interpretation of functional and lexical heads, Utrecht, Led, OTS. 
Major Trends in Theoretical and Applied Linguistics 